al emphasis, the other calling for more systematic attention to class formation within comparative capitalist development. Neither, he observed, integrates gender. Surveying the work in women's history, Fink remarked that gender also has failed to provide a sufficiently inclusive or satisfying analysis. He concluded, however, that gender history has endowed the old culturalist current with a "tougher, more self-critical angle of analysis" and therefore could lead toward a synthesis based on a "second act of culture-centered studies."

To transcend the class/gender dichotomy, Alice Kessler-Harris suggested that we step back and take a long view of history and the way that "work" - and by extension, labor history - became constructed historically as male and workplacecentered. Kessler-Harris noted that wage work is a mere "blip" in the history of labor; she suggested redefining and broadening the concept of "work." embedding it in a context that recognizes the persistence of household and community throughout and beyond the period of industrialization. In conclusion. KesslerHarris suggested that reconceptualizing work around the household and community might enable a reconceptualization of class that would recognize the "significant, perhaps crucial" role in which gender and other elements of human identity affect the formation of class.

Judging by the level of controversy engendered by Kessler-Harris's remarks and the intriguing possibilities evident in the papers presented, the labor history "impasse" promises to open up an even more fruitful dialogue within the tribe.

\title{
Social Science History Association
}

\author{
David R. Smith
}

Wayne State University

Several hundred people, from a wide range of disciplines, gathered in New Orleans between 31 October and 2 November, 1991 for the sixteenth annual meeting of the Social Science History Association (SSHA). While the Labor Network of the SSHA organized thirteen sessions, many of the other 105 sessions also dealt with issues of interest to students of labor and working-class history. Unfortunately, many panels had to run concurrently.

A session entitled "General Strikes and Labor Strategies in Comparative Perspective" featured papers by Roberto Franzosi (University of Wisconsin, Madison), Daniel Greenberg (Pace University), and Tony Rosenthal (University of Kansas). In his paper, "The Red Years (1919-1920): The Factory Movement in Italy," Franzosi discussed the data he compiled on class conflict after computerizing numerous Italian socialist and working-class newspapers. Greenberg's essay, "The 1919 Winnipeg, Seattle, and Buenos Aires General Strikes," suggested, as did Franzosi's, that the employers and the police served as the catalyst for violence 
during these periods of worker protest. In the final paper of the session, "Transport Workers as Catalysts for General Strikes in Latin America: Montevideo, 1911 and Guayaquil. 1922," Rosenthal asserted that the meetings at which workers organized the strikes, not the protests themselves, formed the central events that needed to be studied. As chair and commentator of the session, William Staples (University of Kansas) applauded the panelists for their efforts to understand the responses of employers and the state and to de-emphasize the actual strike events. He also suggested a comparative study of general strikes with situations where they did not occur might help scholars better understand the causes for this form of worker protest. Together, the panelists and audience agreed that as a labor strategy, general strikes served only as a short-term goal of worker protest, and that they seemed to fall apart because the movements lacked a consensus on their long-term objectives.

In another session, Kathleen Canning (University of Michigan), Elizabeth Faue (Wayne State University), Laura Frader (Northeastern University), and Eric Weitz (St. Olaf College) read papers that examined "Gender and Labor Politics in the Interwar Years." In "Women and the Labor Movement in 20th-Century Germany." Canning asserted that following World War I a "feminization of politics" occurred in the textile industry - that the politics of the body had become part of the politics of the union. Faue's paper, "Gender and Working Class Organization in the U.S. during the Interwar Years," explored the transformation from the community to the shop floor as the central arena for union organizing. She argued that the state played a major role, through New Deal legislation, in minimizing the community's position in organized labor and that along with the shift to the shop floor came a rise in masculine images within the working-class movement. Frader's discussion of "Gender and the Labor Movement in Interwar France" suggested that gender politics tried to keep women in the work force while at the same time maintaining their image as mothers. Finally, Eric Weitz presented slides for his discussion of "Communist Parties and the Representation of Gender." From his review of pictures and illustrations in communist and other working-class periodicals. Weitz concluded that although the goals of the various parties determined the articulation of gender, most often they depicted the "heroic labor" of males as the catalyst for socialist transformation. Comments by Eve Rosenhaft (University of Liverpool), Judith Wishnia (SUNY, Stony Brook), and Elizabeth Domansky (University of Washington) highlighted the common themes of these papers and reminded scholars to continue looking beyond the shop floor in order to determine how the wider social-political events of a particular era influenced the working class.

Stephen Meyer (University of Wisconsin, Parkside) chaired a session entitled, "New Workers, New Strategies: The Recomposition of the American Labor Force and Labor Organizing in the Postwar Era," which featured papers by Laura Dresser (University of Michigan) and Sherrie A. Kossoudji (University of Michigan), David R. Smith (Wayne State University), and Heather A. Thompson (Princeton 
University). Dresser and Kossoudji's paper, "Why Did Women Retreai From the Industrial Labor Force in the Post World War II Period?," presented a statistical profile of the reasons for female departure from the Ford River Rouge factory. Smith's paper on "Farm Labor Organizing" suggested that the state's willingness to provide agribusiness with foreign labor effectively undercut the organizing efforts of the United Farm Workers. Finally, Heather Thompson's paper. "The "New' Industrial Workers and the Transformation of Organizing and Labor Relations, 1950-1980," contended that the leaders of the United Auto Workers cooperated with Chrysler to end militant protest by black workers between 1950 and 1973 and, consequently, led the union to accept reforms that weakened their position within the workplace. In her comments. Linda Blum (University of Michigan) concluded that the papers revealed the continued use of ethnic racial, and gender hierarchies to thwart workers' ability to control their labor.

Rather than being organized around any one particular topic or issue, the conference offered a variety of panels that addressed many of the current themes in the study of working-class history. This approach illustrated the ever-expanding focus of working-class history and its attempt to engage such issues as race. gender, immigration, and the state. Within this context the conference highlighted the continuing effort to understand the complexity of the world in which workers. their families, and the rest of society have interacted.

\title{
Colloquium on Popular Politics in the Netherlands, Sixteenth to Nineteenth Centuries
}

\author{
Maarten Prak \\ University of Utrecht
}

This colloquium, held on June 14, 1991 at the Netherlands Institute for Advanced Study in Wassenaar, was a follow-up to a meeting in September 1988 at the Lniversity of Leiden devoted to "Collective Action-Dutch reflections on the Work of Charles Tilly." This time, the focus shifted from riots, rebellions. and (potential) revolutions to the more general theme of popular participation in politics before the age of mass democracy. With this shift of emphasis, the organizers sought to explore, through the history of one particular part of Europe, the possibilities of an encompassing view of the role of subjects in a political system that denied them formal representation. The term "popular politics" was understood to include different forms of collective action, while taking into account other means of political expression by those formally excluded from participation in the system.

Wayne Te Brake's (SUNY. Purchase) introductory paper, "Reconstructing the History of Popular Politics in Europe, 1500-1850," set out to explore the theme 